\title{
Peran Gembala Sidang Sebagai Pendidik Dalam Pertumbuhan Rohani Jemaat
}

\author{
Arozatulo Telaumbanua ${ }^{1)^{*}}$ \\ ${ }^{1}$ Sekolah Tinggi Teologi Anugerah Misi Nias Barat \\ ${ }^{*}$ Email: aro89tel@yahoo.co.id
}

Diterima:27 Mei. 2019 / Direvisi:21 Nov. 2019 / Disetujui:04 Des. 2019

\section{Abstrak}

Peran gembala sidang sebagai pendidik dalam pertumbuhan rohani jemaat, memiliki korelasi yang sangat signifikansi. Gembala sidang memiliki peran penting dalam memberikan pertumbuhan rohani kepada jemaat Tuhan. Gembala sidang memiliki peran sebagai pendidik, yakni mendidik, mengajar dan membimbing jemaat kepada pengenalan dan pertumbuhan rohani yang baik. Melalui Firman Tuhan yang diajarkan kepada jemaat, mereka semakin memahami dan hidup di dalamnya dengan efektif dan menjadi pelaku Firman Tuhan. Pertumbuhan rohani jemaat dapat mempengaruhi kualitas dan kuantitas jemaat Tuhan secara konsisten. Berdasarkan hasil penelitian menujukkan bahwa pertumbuhan rohani jemaat dipengaruhi oleh peran gembala sidang sebagai pendidik, yakni: pada tabel 2 menunjukkan 86,7\% responden yang menjawab setuju, $10 \%$ yang menjawab ragu-ragu dan 3,3\% yang menjawab tidak setuju dan pada tabel 5 menunjukkan ada ada $66,7 \%$ responden yang menjawab setuju, $26,7 \%$ yang menjawab ragu-ragu dan $6,6 \%$ yang menjawab tidak setuju. Jadi, peran gembala sidang sebagai pendidik mampu mempengaruhi pertumbuhan rohani jemaat di Gereja Pentakosta Indonesia Orahili Kota.

Kata Kunci: Peran, Gembala Sidang, Pendidik, Pertumbuhan Rohani

\section{Abstract}

The function of the pastor as a teacher in the church's spirituality growth has a very significant correlation. Pastor has an important function 
in providing spirituality growth to the congregation. As a teacher, which namely to educate, Pastor has to teach and guide to the introduction and good spirituality growth. Through the Word of God, Pastor educates the congregation to understand and live in the world effectively and become doers of God's Word. The spirituality growth of the church can affect the quality and quantity of the Lord's church consistently. Based on the results of the study indicate that the spirituality growth of the congregation is influenced by the function of the pastor as a teacher, namely: in table 2 shows $86,7 \%$ respondents who answered agree, $10 \%$ who answered doubtfully and 3,3\% who answered disagreed and in table 5 shows 66,7\% respondents who answered agree, 26,7\% who answered doubtfully and $6,6 \%$ who answered disagreed. So, the function of the pastor as a teacher is able to influence the spirituality growth of the congregation in the Indonesia Pentacostal Church of Orahili Kota.

Keywords: Function, Pastor, Teacher, Spirituality Growth

\section{Pendahuluan}

Gembala sidang memiliki peran yang sangat penting dalam pertumbuhan rohani jemaat Tuhan. Peran seorang gembala sidang dalam hal ini yang paling utama adalah melayani jemaat. Seorang gembala menerima perintah dari surga dan harus melakukannya, apapun yang akan terjadi, karena pada akhirnya dia akan mempertanggungjawabkannya kepada Allah. Karena itu seorang gembala harus melayani Allah dengan sungguhsungguh, hari demi hari. Seorang gembala sidang bertanggung jawab dalam hal menggembalakan, memelihara, menjaga mengawasi domba-domba yang dipercayakan kepadanya, baik secara kualitas maupun kuantitas. Oleh sebab itu, peran seorang gembala dalam pengembalaan adalah memimpin dan memelihara anggota-anggota gereja dan orang-orang lain, serta memberitakan Injil dan seluruh Firman Allah.

Di samping aspek penggembalan, gembala sidang memiliki peran sebagai pendidik yang bertanggung jawab untuk mendidik, mengajar dan membawa jemaat Tuhan kepada pertumbuhan rohani yang maksimal dan menjadikan setiap jemaat mengerti tentang nilai-nilai kehidupan, sehingga kehidupan bersama segenap anggota gereja dapat terpelihara dengan baik. Melalui perannya sebagai pendidik, seorang gembala memelihara gereja 
dalam perdamaian dan kasih persatuan yang mengakibatkan jemaat semakin bertumbuh ke arah Yesus secara sempurna.

\section{Metode Penelitian}

Metode yang penulis gunakan dalam penelitian adalah metode penelitian kuantitatif. Tempat dan waktu penelitian dilaksanakan di Gereja Pentakosta Indonesia Jemaat Orahili Kota mulai pada bulan September sampai dengan pertengahan bulan November 2019. Jumlah populasi penelitian seluruh jemaat GPI Orahili Kota, yakni 305 orang. Sampel dalam penelitian ini 30 orang. Teknik pengumpulan data terdiri atas pengamatan, penyebaran angket, pengumpulan angket dan perhitungan hasil angket.

\section{Pembahasan \\ Definisi Gembala}

Secara umum istilah gembala menunjuk pada seseorang yang bertugas dan bertanggung jawab untuk memelihara ternak. Kamus Besar Bahasa Indonesia mendefinisikan gembala sebagai seorang pembimbing dan pemelihara kawanan domba. ${ }^{1}$ Douglas mencoba mengartikan kata gembala secara harfiah, yang mengacu pada pada zaman dulu dan sekarang, yaitu sebuah tugas yang mengemban panggilan dengan banyak tuntutan, dan panggilan itu setua panggilan Habel (Kejadian 4:2). ${ }^{2}$ Pribadi yang dipercayakan untuk melakukan tugas sebagai gembala adalah seseorang yang memiliki posisi sebagai pemimpin. Wongso mengatakan bahwa teologia pengembalaan juga disebut ilmu kepemimpinan pengembalaan (Pastoral Leadership). ${ }^{3}$

Secara teologis, istilah gembala menunjuk pada tindakan perawatan dan pemeliharaan yang dilakukan oleh seseorang secara intensif yang tidak mengenal waktu maupun situasi dan tidak dapat diwakili oleh pribadi lain. Kamus Alkitab menjelaskan bahwa gembala adalah tugas yang sangat penting di Israel untuk pemeliharaan, ini terletak pada ketergantungan

\footnotetext{
${ }^{1}$ Suharso dan Ana Retnoningsih (ed.), Kamus Besar Bahasa Indonesia (Semarang: Widya Karya, 2011), 153.

2 J. D. Douglas, Ensiklopedi Alkitab Masa Kini Jilid I (Jakarta: Yayasan Komunikasi Bina Kasih, 2011), 330.

${ }^{3}$ Peter Wongso, Theologia Pengembalaan (Malang: Literatur SAAT, 2009), 1.
} 
seseorang pada domba (ternak)". ${ }^{4}$ Penjelasan di atas mau menegaskan bahwa istilah 'gembala' dapat dipahami dari dua sisi; yang pertama menunjuk pada tugas untuk merawat dan memelihara ternak, binatang piaraan; dan kedua, dalam pengertian rohani, menunjuk pada tugas yang dipercayakan Allah kepada seseorang untuk menjadi perawat atau pemelihara jiwa umat manusia (umat Allah).

Tuhan Yesus adalah Gembala Agung (1 Petrus 5:4). Dalam Perjanjian Lama beberapa tokoh yang dikenal sebagai gembala antara lain: Habel (Kejadian 4:2), Abraham (Kejadian 12:16; 13:2-7), Yakub (Kejadian 29:33), dan demikian juga dengan Yusuf. Dengan melihat para tokoh Alkitab di atas, dapat disimpulkan bahwa gembala adalah pribadi yang dipercayakan oleh Tuhan dalam mendidik, membimbing, mengajar dan membawa jemaat kepada pengenalan Firman Tuhan yang menuju pada satu tujuan adalah bertumbuh ke arah Dia secara sempurna (Efesus 4:11-16).

\section{Gembala Sidang Sebagai Pendidik}

Sangat jelas bahwa gembala sidang tidak hanya menggembalakan dan memberitakan Injil saja, tetapi juga mendidik, mengajar jemaat secara efektif, kreatif, inovatif dan dinamis serta melaksanakan pembelajaran secara aktif, kreatif, efektif dan menyenangkan. Dengan pendidikan seperti ini, pertumbuhan rohani jemaat dapat terjadi. Gembala sidang memiliki peran penting dalam mendidik jemaat. Tentu pendidikan yang dilaksanakan akan memengaruhi pertumbuhan rohani jemaat. Laia mengatakan bahwa pengalaman rohani yang penuh berkat dan sukacita harus dibagikan kepada orang lain supaya mereka merasakan kasih yang kita rasakan. ${ }^{5}$ Kesaksian ini merupakan hasil pertumbuhan rohani jemaat yang ingin mereka bagikan kepada sesama manusia.

Peran gembala sidang sebagai pendidik dalam proses pembelajaran Pendidikan Agama Kristen kepada jemaat akan memengaruhi rohani jemaat terhadap pelajaran (Firman Tuhan) yang diajarkan. Jika gembala sidang sebagai pendidik dalam pembelajaran mampu berperan baik, misalnya selalu memersiapkan materi yang akan diberikan, mampu menciptakan

\footnotetext{
${ }^{4}$ W. R. F. Browning, Kamus Alkitab (Jakarta: BPK Gunung Mulia, 2011), 116.

${ }^{5}$ Kejar Hidup Laia, Prinsip Kedatangan Tuhan Yesus Kedua Kali (Nias Barat:

STTAM, 2019), 134.
} 
suasana yang sehat di dalam kelas persekutuan dan selalu memantau pekerjaan dan tugas yang diberikan kepada jemaat serta mampu memotivasi jemaat untuk membaca Alkitab, berdoa dan bersekutu, maka hal itu dapat menumbuhkan kerohanian jemaat. Telaumbanua dalam pandangannya mengatakan, "Ia menjadi gembala dengan menjadi teman dekat anak-anak, menjadi penasehat yang baik bagi anak-anak, menjadi imam (juru doa) kepada anak-anak, menjadi sahabat, menjadi teladan, menjadi pahlawan, dan menjadi orang tua bagi mereka yang membutuhkan pertolongan rohani. ${ }^{6}$

Seorang gembala sidang memiliki tugas dan tanggung jawab yang sangat kompleks karena ia memiliki tugas yang berlapis, yaitu sebagai pengkhotbah, pemimpin di gereja, dan seklaigus sebagai pendidik bagi jemaat. Jededa T. Pasumah Sentosa, dalam Andar Ismail, dengan mengatakan bahwa Guru PAK tidak hanya bertugas sebagai pengajar tetapi juga pengasuh, pembina dan pendidik yang menyampaikan injil bukan hanya dalam bentuk pelajaran tetapi terlebih dalam keteladanan yang dinampakkan dalam hidupnya. ${ }^{7}$ Demikianlah seorang gembala sidang yang harus mendidik jemaat untuk menjadi jemaat yang bertumbuh imannya, dewasa dan Kristus dan memiliki karakter Kristus.

\section{Pentingnya Panggilan Gembala Sebagai Pendidik}

Penggembalaan tidak boleh dilakukan dengan terpaksa, karena penggembalaan merupakan panggilan yang diniati dalam hati. Nur Anggraito mengatakan, "Pelayanan pengembalaan juga tidak boleh dipakai sebagai usaha mencari keuntungan, sebaliknya harus dilaksanakan dengan dorongan pengabdian. Jika kita memang memiliki kerinduan untuk memperoleh keuntungan sebaliknya tidak usah menjadi seorang gembala sidang." $" 8$

${ }^{6}$ Arozatulo Telaumbanua, Ajarlah Mereka Melakukan: Mengajar Sekolah Minggu Dengan Efektif, Kreatif, Inovatif dan Dinamis (Telukdalam: Biro SM, 2017), 7.

${ }^{7}$ Andar Ismail, Ajarlah Mereka Melakukan (Jakarta: Gunung Mulia, 2013), 165.

${ }^{8}$ Nur Anggrailo, Rahasia Dibalik Gembala Sidang (Yogyakarta: Andi Offset, 2012), 101. 


\section{Pertumbuhan Gereja}

Gereja sebagai tubuh Kristus, dipanggil dan ditempatkan di tengahtengah dunia untuk bertumbuh dan berkembang. Pertumbuhan dan perkembangan gereja merupakan suatu keharusan, sehingga rencanarencana dan program-program gereja dapat berjalan dengan baik. Anwari mengatakan bahwa gereja sebagai tubuh Kristus dipanggil dan ditempatkan di tengah-tengah dunia. Penggembalaan gereja meliputi segi kualitatif (berdasarkan mutu) dan kuantitatif (berdasarkan jumlah atau banyaknya). ${ }^{9}$ Dengan demikian pertumbuhan gereja menjadi tugas semua anggota jemaat yang terlibat aktif di dalam pelayanan gereja, baik itu gembala sidang, hamba-hamba Tuhan dan seluruh jemaat, sehingga gereja dapat bertumbuh dan berkembang di dalam Kristus.

\section{Pengembangan Program Gereja}

Salah satu faktor dari lambatnya pertumbuhan dalam gereja adalah kurangnya program gereja yang dilakukan oleh pemimpin dan anggota pengurus gereja. Gereja seringkali mengalami permasalahan dalam segi dana, sarana dan tenaga bahkan kesadaran untuk terlibat aktif dalam kegiatan gereja. Anwari mengatakan bahwa dalam rangka penatalayanan Kristen, perlu ditimbulkan rasa turut memiliki gereja dikalangan warga jemaat. ${ }^{10}$ Dengan demikian usaha pengembangan gereja khususnya berkaitan dengan program-program gereja sangat ditentukan oleh adanya kesadaran anggota jemaat dan juga peranan dari gembala sidang sebagai pendidik secara proaktif dalam menggiatkan rasa kepedulian dan kesadaran anggota pengurus gereja untuk mengambil bagian dalam mengembangkan program-program gereja, seperti Pendalaman Alkitab, katekisasi dan pengajaran melalui kurikulum Pendidikan Agama Kristen.

\section{Tugas Gembala Sidang}

Gembala atau pastor adalah istilah yang dipakai oleh Alkitab bagi seorang pemimpin yang terlibat dalam pelayanan di tengah-tengah jemaat Tuhan. Gembala sidang merupakan seorang pemimpin yang bertanggung

\footnotetext{
${ }^{9}$ M. S. Anwari, Peranan Penatalayanan Dalam Pengembangan Jemaat (Bandung: Gunung Mulia, 1992), 45.

${ }^{10}$ Anwari, 15.
} 
jawab untuk melakukan tugas penggembalaan yang selalu erat kaitannya dengan pertumbuhan kerohanian jemaat. Seorang gembala sidang atau seorang pemimpin pastoral yang profesional membawa gereja sampai mencapai visi dan misi gereja. Bangun mengungkapkan bahwa gereja sebagai salah satu bentuk organisasi organik (hidup) membutuhkan pemimpin pastoral yang mampu menjalankan tugas dan tanggung jawab secara profesional dan mampu membawa gereja mencapai visi dan misi yakni, berpegang kepada kebenaran. Bertumbuh ke arah Dia (Kristus) yang adalah kepala (Efesus 4:15). ${ }^{11}$ Seorang gembala sebaiknya memiliki ciri khas yang tidak terlepas dalam dirinya sebagai gembala, yaitu sukarela, pengabdian diri, rendah hati dan memberikan teladan yang baik dalam mendidik jemaat Tuhan. ${ }^{12}$

Secara khusus, tugas seorang gembala sidang dapat dijabarkan seperti yang tertera di bawah ini:

a. Memelihara

Seorang gembala sidang dipanggil oleh Tuhan untuk memimpin jemaat Tuhan dan bukan untuk memilikinya. Gembala sidang harus memiliki anggapan bahwa jemaat yang digembalakan adalah orang-orang yang sangat berharga di mata Tuhan sama seperti Tuhan Yesus Kristus yang menganggap berharga seekor domba yang hilang dan mencarinya bahkan meninggalkan domba-domba yang lain (Matius 18:12-14), demikian juga seorang gembala sidang harus menghargai jemaat-jemaat yang digembalakannya. Seorang gembala sidang harus mengerti dan memerhatikan keperluan-keperluan jemaatnya dan mengenal lebih dekat lagi bahkan mengorbankan setiap waktu yang Tuhan berikan kepadanya, karena tugas seorang gembala sidang adalah memelihara setiap anggota gereja atau yang sering disebut jemaat. Ingouf menegaskan bahwa salah satu tugas gembala sidang adalah memelihara anggota-anggota gereja sehingga jemaat yang digembalakan dapat bertumbuh dalam Kristus Yesus. ${ }^{13}$ 2010), 3.

${ }^{11}$ Yosafat Bangun, Integritas Pemimpin Pastoral (Yogyakarta: Yayasan Andi,

${ }^{12}$ Calvin Sholla Rupa, "Ciri Khas Seorang Gembala Berdasarkan Perspektif 1 Petrus 5:1-4”, Jurnal Jaffray, Vol. 14, No. 2, 165.

${ }^{13}$ John E. Ingouf, Sekelumit Tentang Gembala Sidang (Bandung: Lembaga Literatur Baptis, 2009), 39. 
Gembala bertanggung jawab untuk membina, mengasuh, mengarahkan umat Tuhan dengan penuh kasih. Proses pemeliharaan atas jemaat merupakan suatu bentuk pendewasaan. Daud menuliskan bahwa melalui gada dan tongkat, ia menemukan penghiburan, sebab ia menyadari bahwa Tuhan adalah gembalanya yang tidak akan membiarkan dirinya untuk tidak dewasa (Mazmur 23:1-6). Gembala harus memberi kesempatan kepada jemaat untuk berusaha menyelesaikan permasalahan yang di hadapinya tanpa ketergantungan kepada gembala. Proses pendewasaan dapat dilakukan dengan memberi kesempatan kepada jemaat untuk mencoba menangani masalah yang ia hadapi. ${ }^{14}$

b. Memimpin

Seorang gembala sidang dituntut memiliki kemampuan yang besar dalam berbagai aspek. Rasul Paulus menasihatkan Timotius supaya dia menjadi teladan dalam kepemimpinannya sebagai gembala di jemaat Efesus. Gembala sidang dipandang sebagai seseorang yang bisa menjadi panutan dalam segala hal. Bahkan seorang gembala sidang yang baik, tidak akan segan-segan mengorbankan apa yang dimilikinya demi kepentingan jemaatnya; baik tenaga, waktu, perasaan, bahkan materi. Meskipun memiliki keterbatasan dan kelemahan sebagai manusia, seorang gembala tetap dipakai Tuhan untuk berperan dalam pertumbuhan iman jemaat. Dalam hal ini Zaluchu menjelaskan bahwa pemimpin yang punya kemurnian di dalam dirinya, yang motivasinya hanya untuk memuliakan Tuhan dan bertujuan untuk memenangkan jiwa-jiwa bagi Tuhan adalah pemimpin yang dipakai Tuhan. ${ }^{15}$

Seorang gembala sidang harus dapat memimpin diri sendiri sebelum memimpin orang banyak. Untuk menjadi seorang pemimpin yang berhasil maka seorang pemimpin harus mampu mengatasi dan menghadapi setiap persoalan yang timbul di dalam kehidupannya. Hal ini ditegaskan oleh Ingouf yang mengatakan bahwa sebagai manusia,

14 Hal senada juga diungkapkan oleh Santy Sahartian, "Pemahaman Guru Pendidikan Agama Kristen tentang II Timotius 3:10 Terhadap Peningkatan Kecerdasan Spiritual Anak", Fidei: Jurnal Teologi Sistematika dan Praktika, Vol. 1, No. 2, 2018, 150151

15 Sonny Eli Zaluchu, "Respons Tests of Leadership Menurut Teori Frank Damazio Pada Mahasiswa Pascasarjana Jurusan Kepemimpinan Kristen STT Harvest Semarang", Jurnal Jaffray, Vol. 16, No. 2, 151. 
seorang gembala sidang harus mampu menghadapi dan mengatasi persoalan serta mengambil banyak keputusan. Seorang gembala tidak sepatutnya asa, karena ia memiliki kebergantung pada Tuhan dan Tuhan akan memimpin gembala untuk memakai cara yang sistematis untuk memikirkan serta memecahkan persoalan. ${ }^{16} \mathrm{Hal}$ ini menunjukkan bahwa tantangan yang membawa keberhasilan bagi seorang gembala sidang adalah bagaimana cara seorang gembala sidang mengambil keputusan dalam menyingkapi masalah yang bergantung kepada kuasa Tuhan.

c. Pengkhotbah (Pemberita Firman)

Seorang gembala sidang bertanggung jawab untuk memberitakan kebenaran Firman Tuhan (Injil) kepada semua manusia, tanpa dibatasi oleh ruang dan waktu, dan hal ini bukan hanya terbatas di gereja ataupun di kegiatan-kegiatan rutinitas gerejawi. Ini menunjukkan bahwa tugas seorang gembala sidang dalam memberitakan Injil sangat penting dan memberi pengaruh yang besar dalam pertumbuhan rohani jemaat karena apa yang disampaikan oleh gembala sidang dalam khotbah tidak akan lepas dari bagaimana kuasa Tuhan yang bekerja dan terjadi dalam kehidupan orang percaya.

\section{Integritas Gembala Sidang}

Perkembangan gereja pada masa kini sangat ditentukan oleh pemimpin-pemimpin gereja yang profesional dan juga kualitas spiritual yang layak diteladani karena secara tidak langsung seorang pemimpin gereja ataupun gembala sidang adalah sosok pemimpin yang menjadi teladan bagi jemaat. Seorang gembala sidang yang ingin mencapai keberhasilan dalam pelayanan harus memiliki integritas yang baik dan dapat menjadi teladan bagi jemaat yang ia gembalakan. Senada dengan ungkapan di atas, Gea menjelaskan bahwa integritas menjadi modal sangat penting dalam perwujudan kepemimpinan etis, suatu kepemimpinan yang selalu menggunakan pertimbangan-pertimbangan etis dalam setiap kebijakan, keputusan atau tindakan yang diambilnya. ${ }^{17}$ Kehidupan yang berintegritas

\footnotetext{
${ }^{16}$ Ingouf, 25.

${ }^{17}$ Antonius Atosokhi Gea, "Integritas Personal dan Kepemimpinan Etis", Humaniora, 5 (2), 957.
} 
bersumber dari kedewasaan rohani dan psikologis. Kehidupan yang berintegritas adalah kehidupan dalam segala aspeknya memiliki beragam variasi yang berjalan dengan harmonis sehingga menjadi satu kesatuan yang intinya adalah moralitas. Integritas seorang gembala sidang meliputi:

\section{Ketulusan Hati}

Seorang pemimpin Kristen yang berhasil adalah seorang pemimpin yang memiliki ketulusan hati atau motivasi yang benar di hadapan Allah. Motivasi yang salah dalam pelayanan akan merusak moralitas setiap pemimpin, dan hal ini sangat bertentangan dengan kehendak Allah yang menginginkan setiap manusia memiliki ketulusan hati terutama bagi pemimpin gereja atau gembala sidang. Ketulusan hati seorang gembala sidang terlihat dari:

\section{Kesetiaan}

Seorang pemimpin Kristen atau gembala sidang yang berjalan di dalam kehendak Tuhan untuk menggenapi visi dan misi dalam mencapai keberhasilan, akan rela meninggalkan semua agenda pribadi dan menerima agenda Tuhan dalam hidupnya dengan penuh kesetiaan. Warren mengatakan bahwa untuk menggenapi misi maka seorang gembala harus meninggalkan semua agenda pribadinya dan menerima agenda Tuhan untuk hidupnya. ${ }^{18}$ Ini menujukan bahwa kesetiaan seorang gembala dan setiap orang percaya (umat Allah) ditentukan oleh kemampuan untuk bergantung kepada rencana dan kehendak Tuhan.

\section{Kejujuran}

Gembala sidang sebagai pendidik harus jujur dalam melaksanakan tugas dan perannya. Sebagai pendidik yang professional seorang gembala harus memiliki keterampilan dalam mengajar untuk memaksimalkan tugas sebagai hamba Tuhan dan pengajar, baik di gereja maupun di sekolah. ${ }^{19}$

\footnotetext{
${ }^{18}$ Rick Warren, The Purpose Driven Life (Jakarta: Imanuel, 2014), 256.

${ }^{19}$ Arozatulo Telaumbanua, Delapan Keterampilan Dalam Mengajar (Semarang: P2AKSI, 2018), 2.
} 


\section{Kerendahan Hati}

Kerendahan hati merupakan teladan Yesus yang harus dilakukan oleh setiap orang percaya (jemaat). Hal ini diungkapkan oleh Tanihardjo yang mengatakan bahwa ketika Tuhan Yesus menyelamatkan umat manusia, Dia menyelamatkan dengan kerendahan hati. ${ }^{20}$ Setiap gembala sidang harus memiliki sifat rendah hati seperti yang dimiliki oleh Yesus, sehingga pelayanan yang dilakukannya dapat berhasil.

\section{Ketaatan}

Ketaatan merupakan salah satu bagian dari integritas yang dilakukan oleh setiap orang percaya, terutama bagi gembala sidang yang diberi tanggung jawab untuk memelihara jemaat Allah. Dalam ketaatan, seorang gembala sidang akan mendidik dan mengembalakan jemaat, sehingga rohani mereka dapat bertumbuh secara maksimal. Kesetiaan jemaat juga menjadi nyata dalam pertumbuhan rohani tersebut.

\section{Dapat Dipercaya}

Seorang pemimpin yang dapat dipercaya adalah seorang pemimpin yang berintegritas dikarenakan telah teruji dalam menghadapi bermacammacam tantangan. Gereja sangat membutuhkan pemimpin-pemimpin Kristen yang memiliki integritas khususnya berkaitan dengan kepercayaan. Hal ini ditegaskan oleh Bangun dengan ungkapan bahwa seorang pemimpin pastoral hendaknya tidak mencari kepentingannya sendiri. Mereka harus mengutamakan kepentingan jemaat di atas kepentingan sendiri. Sebanyak $88 \%$ jemaat menginginkan pemimpin pastoral berbuat baik pada mereka (jemaat) untuk menyatakan kasih kepada jemaat. ${ }^{21}$ Bandingkanlah hal ini dengan ungkapan Paulus kepada Timotius, "Awasilah dirimu sendiri dan awasilah ajaranmu. Bertekunlah dalam semuanya itu, karena dengan berbuat demikian engkau akan menyelamatkan dirimu dan semua orang yang mendengar engkau ( 1 Timotius 4:16)". Paulus berpesan agar Timotius senantiasa mendapat kepercayaan jemaat.

${ }^{20}$ Budisatyo Tanihardjo, Integritas Seorang Gembala Sidang dan Keberhasilan Pelayanan di Gereja Lokal (Malang: KS, tt), 28.

${ }^{21}$ Bangun, 109. 


\section{Memuridkan Jemaat}

Gembala sidang memiliki tugas dan tanggung jawab untuk memuridkan setiap orang yang sudah percaya kepada Yesus, sehingga mereka dapat dijadikan murid (bdk. Matius 28:19-20). Fances mengatakan bahwa seorang gembala diwajibkan supaya dapat memuridkan orang-orang yang sudah percaya sehingga lebih dewasa dalam iman. ${ }^{22}$ Hal ini sama seperti ketika Yesus memilih kedua belas rasul untuk dijadikan murid-Nya dalam pelayanan pemberitaan Firman Allah.

\section{Konsisten}

Konsisten adalah kesesuaian antara setiap perkataan yang disampaikan dengan setiap perbuatan yang dilakukan. Setiap pemimpin Kristen khususnya pemimpin komunitas dalam gereja atau gembala sidang harus konsisten pada ajaran kebenaran Firman Tuhan. Tanihardjo mengingatkan bahwa setiap pemimpin harus konsisten dalam perkataan maupun perbuatan, sesuai dengan kebenaran Firman Tuhan yaitu doktrindoktrin yang benar dalam Alkitab. ${ }^{23}$

\section{Menjadi Teladan}

Seorang gembala sidang yang menjadi pemimpin rohani, harus dapat diteladani melalui sikap hidup dan perkataan karena kehidupan umat Kristiani selalu disorot dalam segala arah. Gembala sidang sebagai pendidik harus mampu menjadi teladan bagi jemaat sebagai murid yang diajar, dididik dan dibimbing. Telaumbanua menandaskan bahwa seorang guru Agama Kristen atau guru yang beragama Kristen harus dan wajib meneladani metode pengajaran Yesus Kristus. Sebab metode yang Tuhan Yesus gunakan merupakan metode teladan bagi siapa pun guru di dunia ini. ${ }^{24}$ Jika demikian gembala sidang yang berperan sebagai seorang pendidik harus mampu menjadi contoh kepada jemaat dalam segala aspek kehidupannya.

${ }^{22}$ Eddy Fances, Murid Kristus (Jakarta: Yasinta, 2010), 12.

23 Tanihardjo, 48.

${ }^{24}$ Arozatulo Telaumbanua, Teaching Like Jesus (Medan: STTSU-Prodi Teologi, 2018), 65 . 


\section{Peran Gembala Sidang Sebagai Pendidik Dalam Pertumbuhan Rohani Jemaat GPI Orahili Kota}

\section{Defenisi Pertumbuhan Rohani Jemaat}

Pertumbuhan rohani adalah perkembangan kehidupan rohani orang percaya secara berkelanjutan dan meningkat ke arah yang benar serta berkualitas, yang dapat dinilai dari karakter hidup. Hal ini ditegaskan Susanto yang mengatakan bahwa pertumbuhan rohani orang percaya merupakan suatu proses yang aktif, dinamis, berkembanng sehingga mencapai kesempurnaan Kristus. ${ }^{25}$ Pertumbuhan rohani tidak terjadinya begitu saja, tetapi ada faktor yang mendukung pertumbuhan itu, seperti yang diungkapkan oleh Sanders yang mengatakan bahwa orang yang rohani haruslah percaya kepada Tuhan, mengenal Allah, berusaha mencari kehendak Allah, tidak menonjolkan diri sendiri, mencari dan mengikuti cara Allah, suka menaati Allah, didorong oleh kasih Allah dan manusia, serta bergantung kepada Allah. ${ }^{26}$ Hal senada juga dikatakan oleh Setiawan yang menjelaskan bahwa setiap orang beriman harus bisa melihat dan memilih gereja mana yang paling cocok dan paling baik bagi pertumbuhan rohani mereka. Sekalipun semua gereja sama, tetapi harus disadari bahwa semua gereja berbeda." 27

\section{Aspek-Aspek Pertumbuhan Rohani Jemaat}

Pertumbuhan rohani memiliki beberapa aspek, dan aspek-aspek tersebut mengarah kepada kehidupan yang memiliki kaitan langsung dengan Allah, khususnya dalam pengakuan iman. Adapun aspek-aspek pertumbuhan rohani jemaat meliputi:

\section{a. Iman}

Iman kepada Yesus Kristus akan melahirkan keselamatan, karena iman Yesus Kristus, sang penebus dosa manusia, merupakan kepastian bagi setiap orang percaya. Dengan iman kepada Yesus Kristus, setiap orang percaya bahwa Allah telah menerima dan mengampuni dosa-dosa

${ }^{25}$ Gideon Hery Susanto, Tesis (Yogyakarta: STT Kadesi, 2013), 82.

${ }^{26}$ Oswald Sanders, Kepemimpinan Rohani (Bandung: Kalam Hidup, 1979), 22.

${ }^{27}$ Jonatan Setiawan, Tolong Saya Mau Bertumbuh (Yogyakarta: Impact Publishing, 2006), 8. 
mereka. Roh Kudus bersaksi bersama-sama orang beriman bahwa ia adalah anak Allah (Yohanes 3:36). Roh Kudus memberikan kesaksian terhadap kebenaran itu, sehingga orang percaya memiliki keyakinan iman yang teguh. ${ }^{28}$

\section{b. Pertobatan}

Pada hakikatnya pertobatan adalah perubahan pikiran. Akan tetapi, pertobatan terdiri atas tiga aspek: yang menyangkut pikiran, perasaan hati, dan kehendak. ${ }^{29}$ Bertobat adalah upaya kembali kepada Allah setelah meninggalkan semua dosa dan pelanggaran. Wongso menjelaskan arti pertobatan, yaitu kata Yunani metanoia, yang berarti 'berjalan kembali', 'mengubah pikiran' (menuju/kembali kepada Tuhan). Perjanjian Lama memakai istilah nakham dan syuv. Nakham berarti 'menyesal' yang disertai juga dengan adanya perubahan dalam rencana dan tindakan. Syuv mengandung makna 'pertobatan', yaitu kembali kepada Dia dari dosa yang telah memisahkan manusia dengan Tuhan. Jika nakham dinyatakan dari hati dan perbuatan, maka hal ini mengandung makna sebagai kesedihan serta pertobatan." 30

Allah memerintahkan manusia agar bertobat dari dosa-dosanya (Kisah Para Rasul 17:30), dan berpaling kepada keselamatan yang dari Allah (Yesaya 45:22; Ratapan 3:40). Secara khusus Marantika menjelaskan bahwa pertobatan adalah langkah utama yang tak dapat dilewati manusia apabila hendak bebas dari kesesatan, kehancuran mutlak dan total yang sedang menanti itu. Kebinasaan itu adalah hukuman yang pasti (Lukas 13:3, 5). ${ }^{31}$ Pertobatan bukan sekadar kesadaran/keinsyafan akan dosa atau penyesalan akan dosa-dosa (Lukas 18:13), tetapi perubahan pikiran berkenaan dengan dosa dalam hubungannya dengan Allah, bahkan secara positif dan aktif berpaling kepada Tuhan serta meninggalkan semua dosa. Dalam hal ini Murray menjelaskan bahwa pertobatan pada hakikatnya meliputi perubahan hati, pikiran, dan kehendak. Perubahan ini secara prinsip berkaitan dengan

\footnotetext{
${ }^{28}$ H. A. Ironside, Jaminan Yang Pasti (Bandung: Yayasan Kalam Hidup, t.t), 34.

${ }^{29}$ Henry C. Thiessen, Teologi Sistematika (Malang: Gandum Mas, 2002), 410.

${ }^{30}$ Peter Wongso, Soteriologi (Doktrin Keselamatan) (Malang: SAAT, 2000), 49-51.

${ }^{31}$ Chris Marantika, Doktrin Keselamatan dan Kehidupan Orang Percaya
} (Yogyakarta: Iman Press, 2009), 77. 
empat hal, yaitu: perubahan pikiran berkenaan dengan Allah, diri sendiri, dosa dan dengan kebenaran. ${ }^{32}$

\section{c. Lahir Baru}

Ungkapan kelahiran baru berasal dari bahasa Yunani, genethe anothen yang bearti 'dilahirkan kembali' (Yohanes 3:3, 5). Kata anothen berarti 'kembali' dan juga 'dari atas' (Yohanes 3:3; 19:11). Kombinasi dari kata genethen dan anothen mempunyai pengertian lahir baru. Keselamatan membawa hidup yang baru di dalam Kristus, di mana setiap aspek dari kehidupan Kristen dihubungkan dengan keberadaan di dalam Kristus. Yesus pertama kali menyatakan bahwa kelahiran baru secara rohani merupakan sesuatu yang mutlak dibutuhkan untuk memasuki kerajaan Allah (Yohanes 3:3). Untuk mendapatkan keselamatan kelahiran harus terjadi di dalam pribadi orang tersebut, jika tidak maka tidak akan melihat kerajaan Allah. ${ }^{33}$

Kelahiran baru bukanlah perbaikan atau usaha manusia, melainkan semata-mata pekerjaan Tuhan yang mengubah kelakuan dan memperbaharui tabiat manusia; Marantika menegaskan bahwa lahir baru melibatkan pengertian ciptaan baru, hidup lagi, perpindahan dari maut, pembaharuan, pemberian kodrat baru, yaitu kodrat Allah, dan tujuan hidup baru. ${ }^{34}$ Ini tentunya lebih dari pada sekadar emosi indah belaka. Kelahiran baru adalah pengalaman yang esensial dalam iman Kristen.

Kelahiran baru, juga mendukung pertumbuhan rohani jemaat Tuhan. Tanpa adanya kelahiran baru, maka tidak ada pertumbuhan rohani yang terjadi, Pasaribu mengatakan bahwa pengenalan akan Yesus menghasilkan pengakuan yang benar bahwa Yesus adalah Mesias Anak Allah. ${ }^{35}$ Pengenalan ini akan menghasilkan kehidupan yang bertumbuh di dalam Kristus, di dalam kasih-Nya dan kebenaran Injil.

${ }^{32}$ John Murray, Penggenapan dan Penerapan Penebusan (Surabaya: Momentum Christian Literature, 1999), 141.

${ }^{33}$ Hal yang senada juga diungkapkan oleh Asih Rachmani Endang Sumiwi, “Analisis Biblika Baptisan Roh Kudus dan Penuh dengan Roh Kudus", Fidei: Jurnal Teologi Sistematikan dan Praktika, Vo. 1, No. 1, 2018, 7.

${ }^{34}$ Marantika, 91.

${ }^{35}$ Marulak Pasaribu, Tafsiran Injil Sinoptik (Malang: Gandu Mas, 2006), 283. 


\section{d. Hasil Iman}

Di dalam Tuhan setiap orang percaya beroleh keberanian dan jalan masuk kepada Allah dengan penuh kepercayaan oleh iman kepada-Nya (Efesus 3:12). Hal ini ditegaskan oleh Nahuway yang mengatakan, "Keberanian kita tidak terletak pada iman kita yang dengan cepat berubah menjadi takut. Keberanian kita yang melebihi kekuatan kita berakar pada iman Yesus Kristus yang tinggal di dalam kita, yang oleh Dia kita hidup, bergerak dan menemukan identitas kita." ${ }^{36}$ Yesus telah mati agar manusia memiliki kehidupan yang kekal di dalam Kerajaan Allah. Oleh karena itu, melalui iman setiap orang percaya akan mendapatkan keselamatan, kepastian dan perbuatan baik. Inilah hasil iman kepada Yesus Kristus, yaitu hidup yang bertumbuh dan berkenan kepada untuk diselamatkan.

\section{Keselamatan}

Thiessen pernah mengatakan bahwa seluruh keselamatan bergantung pada iman. Dari awal sampai akhir manusia diselamatkan oleh iman, apakah itu pembenaran (Roma 5:1), pengangkatan sebagai anak atau adopsi (Galatia 3:5, 14; 4:5, 6), atau pengudusan (Kisah Para Rasul 26:18). ${ }^{37}$ Kasih karunia Allah akan menyelamatkan manusia melalui iman kepada Kristus. Hal ini juga yang dikatakan oleh Marantika, bahwa bukan karena Allah beraksi karena amarah (orge) oleh karena terpojok dengan ular/Setan, melainkan merupakan suatu tindakan proaktif, spontan, dan terencana dengan tuntas di masa lampau oleh Allah untuk menyelamatkan manusia. ${ }^{38}$

Kekuatan kasih karunia membuat manusia (orang percaya) terhindar dari murka Allah atau hukuman Allah. Keselamatan tersebut diberikan Allah bukan karena suatu hal baik yang diperbuat manusia, tetapi semuanya hanyalah karena kemurahan hati-Nya. Dengan iman manusia diselamatkan dan akan beroleh kehidupan kekal di dalam kekekalan.

${ }^{36}$ Jacob Nahuway, 7 Langkah Mengalami Kuasa Tuhan, Mujizat Masih Ada (Jakarta: GBI Jemaat Mawar Saron, 2010), 77.

37 Thiessen, 418.

${ }^{38}$ Marantika, 7. 


\section{Kepastian}

Orang yang beriman kepada Kristus memiliki kepastian hidup. Memang benar bahwa kepastian keselamatan datangnya dari kesaksian Roh Kudus (Roma 8:16; 1 Yohanes 3:24; 4:13), namun Allah menunjukkan janji-janji dalam Firman-Nya kepada jiwa, dan kepastian datang pada saat percaya pada janji-janji itu. Yang berkaitan erat sekali dengan kepastian ialah damai sejahtera (Yesaya 26:3; Roma 5:1), dan pemberhentian (Ibrani 4:3), beserta dengan sukacita yang dihasilkannya (1 Petrus 1:8).

\section{Perbuatan Baik}

Iman di dalam Kristus akan memimpin seseorang untuk melakukan perbuatan baik. Thiessen mengatakan bahwa iman akan menghasilkan perbuatan baik. Manusia diselamatkan bukan karena perbuatann baiknya (Roma 3:20; Efesus 2:9), melainkan untuk melakukan perbuatan baik (Efesus 2:10)." ${ }^{39}$ Artinya, kehidupan yang bertumbuh harus nyata di dalam kehidupan sehari-hari, sebab itulah iman yang sesungguhnya. Dalam hal ini perlu diingat firman Yesus yang mengatakan, "Demikianlah hendaknya terangmu bercahaya di depan orang, supaya mereka melihat perbuatanmu yang baik dan memuliakan Bapamu yang di sorga" (Matius 5:16). Ini artinya, iman di dalam Yesus Kristus akan menunjukkan kebenaran yang ada melalui pekerjaan Roh Kudus. Yakobus juga menekankan bahwa iman diwujudkan dalam perbuatan (Yakobus 2:17-26). Perbuatan baik ini adalah buah Roh (Galatia 5:22-23; Efesus 5:9), yaitu yang erat kaitannya dengan pertumbuhan rohani.

\section{Hidup Dalam Kebersamaan}

Kalimat 'Sebab tidak ada perbedaan antara orang Yahudi dan orang Yunani' secara sederhana dapat didefinisikan bahwa dalam diri orang percaya tidak ada perbedaan, baik organisasi gereja, suku, atau budaya, karena semuanya berada dalam satu kesatuan di dalam Kristus. ${ }^{40}$ Dalam Galatia 3:28 disebutkan, "Dalam hal ini tidak ada orang Yahudi atau

${ }^{39}$ Thiessen, 418.

${ }^{40}$ Perhatikan bahwa kata 'perbedaan' berasal dari bahasa Yunani, diastole, yang memiliki arti 'memisahkan, membedakan, perbedaan.' Lih. Harold K. Moulton, Leksikon Analitis Bahasa Yunani (Yogyakarta: Randa’s Family Press, 2007), 88. 
orang Yunani, tidak ada hamba atau orang merdeka, tidak ada laki-laki atau perempuan, karena kamu semua adalah satu di dalam Kristus Yesus." Hal ini menunjukkan bahwa seluruh manusia disatukan di dalam kasih dan iman kepada Yesus Kristus. Paulus berkata kepada Filemon agar menerima Onesimus dengan kasih. Kasih yang diinginkan oleh Paulus adalah kasih yang tidak mengenal batas sosial. Meskipun Onesimus adalah seorang hamba atau budak tetapi tetap harus dikasihi sebagai sesama orang Kristen. Ketiadaan perbedaan ini menunjukkan bahwa di dalam Kerajaan Allah seluruh manusia adalah saudara. Karena itu, sangatlah penting untuk memahami makna kehidupan di dalam Yesus Kristus agar manusia memiliki konsep dan perilaku seperti yang Tuhan kehendaki dalam kehidupan setiap orang percaya kepada-Nya.

\section{Saling Mengasihi}

Kehidupan yang bertumbuh di dalam Kristus yang didasarkan pada iman dan kasih Kristus adalah kehidupan yang aplikatif. Walaupun demikian, setiap manusia Kristus harus mengatakan bahwa karya Roh Kudus ini merupakan suatu proses yang tidak sekali jadi, karena masih juga berperang melawan kemanusiaan yang lama yang dikuasai oleh keinginan daging. ${ }^{41}$ Kebenaran ini ditentukan di dalam perintah baru yang dinyatakan oleh Tuhan Yesus dalam Yohanes 13. Jika manusia sudah diperbaharui, akan menghasilkan kehidupan yang berkualitas sehingga bertumbuh secara rohani dan berdampak secara luas. Mengasihi bukan sekadar simpati saja atau pun dalam perkataan saja, seperti yang diungkapkan oleh Saud bahwa kasih itu dinyatakan dalam perkataan dan perbuatan. ${ }^{42}$ Yohanes mengatakan "Anak-anakku, janganlah kita hanya sekedar mengatakan bahwa kita mengasihi orang lain; marilah kita sungguh-sungguh mengasihi mereka dan menunjukkan kasih kita dengan perbuatan kita" (1 Yohanes 3:18, BIS). Saling mengasihi merupakan suatu tanda bahwa orang-orang Kristen adalah benar-benar pengikut Kristus.

\footnotetext{
${ }^{41}$ Lase, 43.

${ }^{42}$ Saud, 213.
} 
Kaya di Dalam Kristus

Konteks ini menunjukkan suatu pemahaman yang benar bahwa orang miskin akan menjadi kaya. Hagelberg menjelaskan bahwa yang dimaksud di sini adalah berkat pertolongan-Nya yang berkelimpahan. ${ }^{43}$ Dengan demikian kekayaan yang dimaksud Paulus bukan saja berupa berkat rohani yang nantinya akan dinikmati di sorga, tetapi mencakup berkat yang dinikmati di dunia ini yang dikaruniakan oleh Roh (рnеuma).${ }^{44}$ Berkat-berkat rohani yang diberikan oleh Roh Kudus kepada orang-orang percaya.

\section{Jemaat Menjadi Saksi Bagi Kristus}

Kehidupan orang percaya yang sudah bertumbuh secara rohani akan mengalami peningkatan kualitas hidup sehingga mampu mendemonstrasikan kerajaan Allah kepada dunia melalui Injil. Paulus menekankan untuk memberitakan Injil kepada semua orang. Penting untuk diketahui bahwa salah satu ciri khas orang yang bertumbuh adalah memberitakan Injil. Amanat Agung menugaskan gereja (orang percaya) untuk pergi keseluruh dunia serta menjadikan semua bangsa murid Tuhan (Matius 28:19). Artinya, gereja bertanggung jawab untuk memberikan kesempatan kepada dunia untuk mendengarkan Injil serta menerima Kristus.

\section{Mengajarkan Kebenaran}

Kebenaran yang dimaksud disini adalah Injil. Orang percaya ditugaskan untuk mengajarkan kebenaran Injil kepada orang lain. Tugas ini salah satu pengaruh atau dampak kehidupan yang bertumbuh secara rohani.

\section{Taat Kepada Allah}

Ketaatan kepada Allah merupakan karakter hidup orang percaya yang bertumbuh secara rohani. Tripp mengatakan bahwa ketaatan adalah kesediaan seseorang untuk tunduk kepada otoritas, dan itu berarti mau

\footnotetext{
${ }^{43}$ Hagelberg, 203.

${ }^{44}$ J. L. Ch. Abineno, Tafsiran Alkitab Surat Efesus (Jakarta: Gunung Mulia, 2001),
} 37. 
melakukan apa yang diperintahkan tanpa alasan, tanpa menunda, tanpa tantangan. ${ }^{45}$ Melalui sikap taat, setiap orang percaya akan menjadi suratsurat Kristus yang terbuka bagi orang lain. Rasa takut dan juga hormat kepada Tuhan Allah harus ada di dalam kehidupan orang percaya, sehingga tunduk kepada otoritas Allah yang memberi kehidupan itu. Ketaatan juga merupakan hal yang sangat penting untuk dimiliki setiap orang percaya, sebab tanpa ketaatan tidak akan mendapatkan kehidupan yang kekal di dalam Kristus. Artinya, ketaatan menunjukkan kualitas kehidupan rohani melalui pengakuan iman dalam hati kepada Yesus Kristus.

\section{Hasil Penelitian}

Setelah dilakukan penelitian terhadap variabel X, yaitu tentang Peran Gembala Sidang Sebagai Pendidik, didapatkan hasil sebagai berikut:

\section{Tabel 1}

Peran Gembala dalam mengajar jemaat

\begin{tabular}{cccc}
\hline Item & $\begin{array}{c}\text { Pilihan } \\
\text { Jawaban }\end{array}$ & Jumlah & Presentase \\
\hline $\mathbf{3}$ & Setuju & 26 & $86,7 \%$ \\
$\mathbf{2}$ & Ragu-Ragu & 3 & $10 \%$ \\
$\mathbf{1}$ & Tidak Setuju & 1 & $3,3 \%$ \\
& Jumlah & $\mathbf{3 0}$ & $\mathbf{1 0 0}$ \\
& & & \\
\hline
\end{tabular}

Berdasarkan hasil tabel di atas dapat dilihat bahwa ada $86,7 \%$ responden yang menjawab setuju, 10\% yang menjawab ragu-ragu dan 3,3\% yang menjawab tidak setuju. 
Tabel 2

Gembala Sidang memiliki tanggung jawab kepada jemaat

\begin{tabular}{cccc}
\hline Item & Pilihan & Jumlah & Presentase \\
& Jawaban & & \\
\hline $\mathbf{3}$ & Setuju & 28 & $93,3 \%$ \\
$\mathbf{2}$ & Ragu-Ragu & 2 & $6,7 \%$ \\
$\mathbf{1}$ & Tidak Setuju & 0 & $0 \%$ \\
& Jumlah & $\mathbf{3 0}$ & $\mathbf{1 0 0}$ \\
\hline
\end{tabular}

Berdasarkan hasil tabel di atas dapat dilihat bahwa ada 93,3\% responden yang menjawab setuju, 6,7\% yang menjawab ragu-ragu dan $0 \%$ yang menjawab tidak setuju.

Tabel 3

Gembala memiliki integritas dalam mengajar jemaat

\begin{tabular}{cccc}
\hline Item & $\begin{array}{c}\text { Pilihan } \\
\text { Jawaban }\end{array}$ & Jumlah & Presentase \\
\hline $\mathbf{3}$ & Setuju & 27 & $90 \%$ \\
$\mathbf{2}$ & Ragu-Ragu & 3 & $10 \%$ \\
$\mathbf{1}$ & Tidak Setuju & 0 & $0 \%$ \\
& Jumlah & $\mathbf{3 0}$ & $\mathbf{1 0 0}$ \\
\hline
\end{tabular}

Berdasarkan hasil tabel di atas dapat dilihat bahwa ada $90 \%$ responden yang menjawab setuju, $10 \%$ yang menjawab ragu-ragu dan $0 \%$ yang menjawab tidak setuju.

\section{Tabel 4}

Gembala Sidang tidak hanya sebagai pengkhotbah

\begin{tabular}{cccc}
\hline Item & Pilihan & Jumlah & Presentase \\
& Jawaban & & \\
\hline $\mathbf{3}$ & Setuju & 29 & $96,7 \%$ \\
$\mathbf{2}$ & Ragu-Ragu & 1 & $3,3 \%$ \\
$\mathbf{1}$ & Tidak Setuju & 0 & $0 \%$ \\
& Jumlah & $\mathbf{3 0}$ & $\mathbf{1 0 0}$ \\
\hline
\end{tabular}


Berdasarkan hasil tabel di atas dapat dilihat bahwa ada 96,7\% responden yang menjawab setuju, 3,3\% yang menjawab ragu-ragu dan $0 \%$ yang menjawab tidak setuju.

Hasil penelitian pada variabel Y, yaitu tentang Pertumbuhan Rohani Jemaat GPI Orahili Kota, sebagai berikut:

Tabel 5

Rohani jemaat bertumbuh karena Gembala Sidang mengajar Firman Tuhan dengan baik

\begin{tabular}{cccc}
\hline Item & $\begin{array}{c}\text { Pilihan } \\
\text { Jawaban }\end{array}$ & Jumlah & Presentase \\
\hline $\mathbf{3}$ & Setuju & 20 & $66,7 \%$ \\
$\mathbf{2}$ & Ragu-Ragu & 8 & $26,7 \%$ \\
$\mathbf{1}$ & Tidak Setuju & 2 & $6,6 \%$ \\
& Jumlah & $\mathbf{3 0}$ & $\mathbf{1 0 0}$ \\
\hline
\end{tabular}

Berdasarkan hasil tabel di atas dapat dilihat bahwa ada 66,7\% responden yang menjawab setuju, 26,7\% yang menjawab ragu-ragu dan $6,6 \%$ yang menjawab tidak setuju.

\section{Tabel 6}

Integritas Gembala Sidang mempengaruhi rohani jemaat

\begin{tabular}{cccc}
\hline Item & $\begin{array}{c}\text { Pilihan } \\
\text { Jawaban }\end{array}$ & Jumlah & Presentase \\
\hline $\mathbf{3}$ & Setuju & 24 & $80 \%$ \\
$\mathbf{2}$ & Ragu-Ragu & 6 & $20 \%$ \\
$\mathbf{1}$ & Tidak Setuju & 0 & $0 \%$ \\
& Jumlah & $\mathbf{3 0}$ & $\mathbf{1 0 0}$ \\
\hline
\end{tabular}

Berdasarkan hasil tabel di atas dapat dilihat bahwa ada $80 \%$ responden yang menjawab setuju, $20 \%$ yang menjawab ragu-ragu dan $0 \%$ yang menjawab tidak setuju. 
Tabel 7

Pertumbuhan rohani jemaat dinyatakan dalam kehidupan sehari-hari

\begin{tabular}{cccc}
\hline Item & $\begin{array}{c}\text { Pilihan } \\
\text { Jawaban }\end{array}$ & Jumlah & Presentase \\
\hline $\mathbf{3}$ & Setuju & 27 & $90 \%$ \\
$\mathbf{2}$ & Ragu-Ragu & 2 & $6,7 \%$ \\
$\mathbf{1}$ & Tidak Setuju & 1 & $3,3 \%$ \\
& Jumlah & $\mathbf{3 0}$ & $\mathbf{1 0 0}$ \\
\hline
\end{tabular}

Berdasarkan hasil tabel di atas dapat dilihat bahwa ada $90 \%$ responden yang menjawab setuju, 6,7\% yang menjawab ragu-ragu dan 3,3\% yang menjawab tidak setuju.

\section{Tabel 8}

Membaca Alkitab, rajin berdoa merupakan bukti pertumbuhan rohani

\begin{tabular}{cccc}
\multicolumn{4}{c}{ jemaat } \\
\hline Item & Pilihan & Jumlah & Presentase \\
& Jawaban & & \\
\hline $\mathbf{3}$ & Setuju & 19 & $63,3 \%$ \\
$\mathbf{2}$ & Ragu-Ragu & 9 & $30 \%$ \\
$\mathbf{1}$ & Tidak Setuju & 2 & $6,7 \%$ \\
& Jumlah & $\mathbf{3 0}$ & $\mathbf{1 0 0}$ \\
\hline
\end{tabular}

Berdasarkan hasil tabel di atas dapat dilihat bahwa ada $63,3 \%$ responden yang menjawab setuju, 30\% yang menjawab ragu-ragu dan $6,7 \%$ yang menjawab tidak setuju.

Dari dari penelitian di atas menunjukkan bahwa peran gembala sidang sebagai pendidik dalam mendidik jemaat sangat signifikan. Artinya, sangat memengaruhi pertumbuhan rohani jemaat di Gereja Pentakosta Indonesia Orahili Kota.

\section{Kesimpulan}

Berdasarkan pembahasan dan hasil penelitian di atas, dapat disimpulkan bahwa gembala sidang memiliki peran yang sangat penting dalam pertumbuhan rohani jemaat. Jemaat membutuhkan Pendidikan 
Agama Kristen melalui penggembalaan yang dilaksanakan gembala sidang. Sebagai pendidik, gembala sidang harus mampu memberikan pengaruh terhadap pertumbuhan rohani jemaat melalui pengajaran Firman Tuhan. Ketika jemaat menerima penggembalaan dan pendidikan dari gembala sidang sebagai pendidik dengan baik, maka jemaat memiliki kehidupan yang berbeda dari sebelumnya, seperti jemaat saling mengasihi, jemaat hidup bersama dan jemaat selalu taat dan mengajarkan kebenaran Firman Allah (memberitakan Injil).

Berdasarkan hasil penelitian yang tertera pada tabel 5, tentang Rohani jemaat bertumbuh karena Gembala Sidang mengajar Firman Tuhan dengan baik, menunjukkan bahwa ada $66,7 \%$ responden yang menjawab setuju, $26,7 \%$ yang menjawab ragu-ragu dan $6,6 \%$ yang menjawab tidak setuju. Artinya pendidikan dan pengajaran Firman Tuhan dengan baik dapat mempengaruhi kehidupan jemaat. Berkaitan dengan pembahasan ini, penulis memberikan beberapa saran, antara lain: pertama, sebagai gembala sidang sebagai pendidik agar lebih memperhatikan kerohanian jemaat terutama masalah kepastian iman dan keselamatan mereka. Kedua, agar gereja melaksanakan programnya dengan baik salah satu yang penting adalah program pengajaran. Ketiga, agar gereja tidak hanya beribadah melainkan mengutus jemaat sebagai saksi bagi Kristus. Keempat, sebaiknya gembala sidang tidak hanya mengembalakan tetapi juga mendidik jemaat menjadi militan dan misioner dalam pelayanan pemberitaan Injil. Kelima, agar gereja tidak hanya menjadi wadah berkumpul tetapi menjadi wadah pendidikan yang menghasilkan jemaat yang kokoh, mampu hidup dalam kesulitan dan siap menghadapi penderitaan.

\section{Daftar Pustaka}

Abineno, J. L. Ch., Tafsiran Alkitab Surat Efesus. Jakarta: Gunung Mulia, 2001.

Anggraito, Nur, Rahasia Dibalik Gembala Sidang. Yogyakarta: Andi Offset, 2012.

Anwari, M. S., Peranan Penatalayanan Dalam Pengembangan Jemaat. Bandung: Gunung Mulia, 1992.

Bangun, Yosafat, Integritas Pemimpin Pastoral. Yogyakarta: Yayasan Andi, 2010. 
Browning, W. R. F., Kamus Alkitab. Jakarta: BPK Gunung Mulia, 2011.

Douglas, J. D., Ensiklopedi Alkitab Masa Kini Jilid I. Jakarta: Yayasan Komunikasi Bina Kasih, 2011.

Fances, Eddy, Murid Kristus. Jakarta: Yasinta, 2010.

Gea, Antonius Atosokhi, "Integritas Personal dan Kepemimpinan Etis", Humaniora, Vol. 5, No. 2.

Ingouf, John E., Sekelumit Tentang Gembala Sidang. Bandung: Lembaga Literatur Baptis, 2009.

Ironside, H. A., Jaminan Yang Pasti. Bandung: Yayasan Kalam Hidup, t.t. Ismail, Andar, Ajarlah Mereka Melakukan. Jakarta: Gunung Mulia, 2013.

Laia, Kejar Hidup, Prinsip Kedatangan Tuhan Yesus Kedua Kali. Nias Barat: STTAM, 2019.

Lase, Jason, Pendidikan Agama Kristen Di Perguruan Tinggi Umum. Bandung: Bina Media Infromasi, 2007.

Marantika, Chris, Doktrin Keselamatan dan Kehidupan Orang Percaya. Yogyakarta: Iman Press, 2009.

Moulton, Harold K., Leksikon Analitis Bahasa Yunani. Yogyakarta: Randa's Family Press, 2007.

Murray, John, Penggenapan dan Penerapan Penebusan. Surabaya: Momentum Christian Literature, 1999.

Nahuway, Jacob, 7 Langkah Mengalami Kuasa Tuhan, Mujizat Masih Ada. Jakarta: GBI Jemaat Mawar Saron, 2010.

Pasaribu, Marulak, Tafsiran Injil Sinoptik. Malang: Gandu Mas, 2006.

Sahartian, Santy, "Pemahaman Guru Pendidikan Agama Kristen tentang II

Timotius 3:10 Terhadap Peningkatan Kecerdasan Spiritual Anak",

Fidei: Jurnal Teologi Sistematika dan Praktika, Vol. 1, No. 2, 2018.

Sanders, Oswald, Kepemimpinan Rohani. Bandung: Kalam Hidup, 1979.

Setiawan, Jonatan, Tolong Saya Mau Bertumbuh. Yogyakarta: Impact Publishing, 2006.

Suharso dan Ana Retnoningsih (ed.), Kamus Besar Bahasa Indonesia. Semarang: Widya Karya, 2011.

Sumiwi, Asih Rachmani Endang, "Analisis Biblika Baptisan Roh Kudus dan Penuh dengan Roh Kudus", Fidei: Jurnal Teologi Sistematikan dan Praktika, Vo. 1, No. 1, 2018.

Susanto, Gideon Hery, Tesis, Yogyakarta: STT Kadesi, 2013. 
Rupa, Calvin Sholla, "Ciri Khas Seorang Gembala Berdasarkan Perspektif 1 Petrus 5:1-4”, Jurnal Jaffray, Vol. 14, No. 2.

Tanihardjo, Budisatyo, Integritas Seorang Gembala Sidang dan Keberhasilan Pelayanan di Gereja Lokal. Malang: KS, tt.

Telaumbanua, Arozatulo, Delapan Keterampilan Dalam Mengajar. Semarang: P2AKSI, 2018.

Telaumbanua, Arozatulo, Teaching Like Jesus. Medan: STTSU-Prodi Teologi, 2018.

Minggu Dengan Efektif, Kreatif, Inovatif dan Dinamis. Telukdalam: Biro SM, 2017.

Thiessen, Henry C., Teologi Sistematika. Malang: Gandum Mas, 2002.

Tripp, Tedd, Mengembalakan Anak Anda. Malang: Gandum Mas, 2002.

Warren, Rick, The Purpose Driven Life. Jakarta: Imanuel, 2014.

Wongso, Peter, Theologia Pengembalaan. Malang: Literatur SAAT, 2009.

Wongso, Peter, Soteriologi (Doktrin Keselamatan). Malang: SAAT, 2000.

Zaluchu, Sonny Eli. "Respons Tests of Leadership Menurut Teori Frank Damazio Pada Mahasiswa Pascasarjana Jurusan Kepemimpinan Kristen STT Harvest Semarang”, Jurnal Jaffray, Vol. 16, No. 2. 